\title{
In Vitro Rearing of Perkinsiella saccharicida and the Use of Leaf Segments to Assay Fiji disease virus Transmission
}

\author{
G. L. Hughes, P. G. Allsopp, S. M. Brumbley, K. N. Johnson, and S. L. O’Neill
}

First, fourth, and fifth authors: School of Integrative Biology, The University of Queensland, Qld 4072, Australia; second author: BSES Limited, P.O. Box 86, Indooroopilly, Qld 4068, Australia; and third author: Australian Institute for Bioengineering and Nanotechnology, c/o BSES Limited, 50 Meier Road, Indooroopilly, Qld 4068, Australia. Accepted for publication 21 February 2008.

\begin{abstract}
Hughes, G. L., Allsopp, P. G., Brumbley, S. M., Johnson, K. N., and O'Neill, S. L. 2008. In vitro rearing of Perkinsiella saccharicida and the use of leaf segments to assay Fiji disease virus transmission. Phytopathology $98: 810-814$.

Fiji leaf gall (FLG) is caused by the Reovirus, Fiji disease virus (FDV), which is transmitted to sugarcane by planthoppers of the genus Perkinsiella. Low vector transmission rates and slow disease symptom development make experimentation within the FDV-Perkinsiella-sugarcane system inherently difficult. A laboratory-based technique was devised to rear the vector using sugarcane leaves as a food source. Planthoppers were reared on sugarcane leaf segments embedded in agarose enclosed

within plastic containers. To provide a nondestructive assay for determination of the inoculation potential of planthoppers, FDV was detected by reverse transcription-polymerase chain reaction (RT-PCR) in newly infected sugarcane leaf segments following exposure to viruliferous planthoppers. Leaf segment inoculation correlated with development of FLG symptoms in whole plants that were fed on by the same planthoppers. Analysis of FDV RNAs within the planthopper, measured by quantitative RT-PCR (qRT-PCR), indicated that FDV RNA concentration was associated with successful inoculation of the leaf segment, transmission of FDV to sugarcane and subsequent development of FLG in plants. Quantification of FDV RNA within planthoppers provided an additional measure to assess vector competence in individuals.
\end{abstract}

Fiji disease virus (FDV), the causal agent of Fiji leaf gall (FLG), is one of the most economically important diseases of the Australian sugarcane industry (6). Sugarcane affected by FLG displays raised galls of leaf tissue, distortion or death of meristematic tissue, and stunting, resulting in dramatic yield reduction (8). Although detectable in both gall and nongall tissues of diseased plants, FDV RNA is on average 200 times higher in gall tissues (23).

FDV is transmitted in a propagative persistent manner by planthoppers of the genus Perkinsiella (13,25). Within Australia, Perkinsiella saccharicida is the only known vector $(10,19)$, although $P$. thompsoni is present in the Ord River region of Western Australia. No mechanical transmission of FDV has been reported. Planthoppers acquire the virus by feeding on FDVinfected plants. Nymphs in the first to third instars are the only life stages that can acquire the virus $(1,9)$. Typically, $15 \%$ of planthoppers in a population will be infected after feeding on FDV-infected sugarcane (11) and less than 50\% of plants develop FLG symptoms when fed on by infected vectors $(9,11)$. Individually, $P$. saccharicida are inefficient vectors of the virus $(2,11)$, but high vector densities on plants result in successful transmission. The low vector competence of individual planthoppers makes laboratory studies of transmission dynamics inherently difficult.

Currently, $P$. saccharicida is reared on caged sugarcane plants in glasshouses (5). While this technique allows for rearing of large numbers of individuals, it is cumbersome to undertake experiments that aim to manipulate the planthopper. Several methods

Corresponding author: S. L. O’Neill; E-mail address: scott.oneill@uq.edu.au

doi:10.1094/PHYTO-98-7-0810

This article is in the public domain and not copyrightable. It may be freely reprinted with customary crediting of the source. The American Phytopathological Society, 2008. are available to rear planthoppers and leafhoppers in vitro on artificial diets, but survival, growth, and development are reduced $(12,17,18)$. Additionally, FLG symptom development in some sugarcane cultivars can be conspicuous and variable, in some circumstances ranging up to several months $(9,24)$. Presently, a nondestructive method for determining the infection status of an individual planthopper or the ability of an individual to inoculate sugarcane with FDV is unavailable. A fast, reliable, inexpensive transmission assay is desirable for research into the biology of this disease and for evaluating strategies for disease control.

We report the development of a novel laboratory-based culture system to rear $P$. saccharicida that enabled the development of a high-throughput screening process to examine virus transmission from the planthopper to sugarcane. Additionally, we investigated the relationship between inoculation of leaf segments in vitro and development of disease in plants in vivo.

\section{MATERIALS AND METHODS}

In vitro growth systems. Sections of sugarcane leaves (cv. NCo310 - a highly susceptible cultivar) (approximately $2 \times 12 \mathrm{~cm}$ ) were embedded in $1 \%$ agarose dissolved in water in a plastic container (height $15 \mathrm{~cm}$, diameter $7.5 \mathrm{~cm}$ ) (Fig. 1). Containers had a gauze opening in the lid to prevent condensation. Planthoppers were introduced into containers with sugarcane leaf segments and were incubated in insect growth cabinets (Phytotora climate simulator, Contherm) under the following conditions: photoperiod $12 \mathrm{~h}$, light intensity $180 \mu \mathrm{E}, 70 \%$ relative humidity, and temperature $28^{\circ} \mathrm{C}$. Sugarcane leaf segments were changed at weekly intervals or when visible signs of necrosis or fungal growth were evident. After exposure to adult planthoppers for approximately 1 week, sugarcane segments were pooled within a new container so that nymphs could emerge from eggs laid in the mid-rib of the sugarcane leaf. Nymphs were subsequently transferred onto fresh sugarcane segments. 
RNA extraction and reverse transcription-polymerase chain reaction. Reverse transcription-polymerase chain reaction (RTPCR) was used to screen for the presence of FDV in leaf segments and insect samples. Samples were homogenized with a mini beadbeater (Biospec Products, Bartlesville, OK) in $1 \mathrm{ml}$ of TRIzol reagent (Invitrogen, Carlsberg, CA) using glass (3 $\mathrm{mm}$ diameter) and steel (3 mm diameter) beads for insect and sugarcane tissue, respectively. RNA extractions were carried out as per manufacturer's protocol. For sugarcane samples, RNA was extracted using the recommended additional steps for tissues with a high content of polysaccharides and quantified spectrophotometrically using a NanoDrop ND-1000 (NanoDrop Technologies, Wilmington, DE). Five hundred nanograms of RNA was treated with 10 units of DNase I (Roche, Basel, Switzerland) in supplied buffer and incubated at $37^{\circ} \mathrm{C}$ for $1 \mathrm{~h}$. RNA was denatured at $99^{\circ} \mathrm{C}$ for $5 \mathrm{~min}$ in the presence of $1.5 \mu \mathrm{M}$ of FDV forward primer (FDV-1) and $1.5 \mu \mathrm{M}$ of either planthopper (PH-F) or sugarcane forward primer (SC-Actin-F) (Table 1) and $500 \mu \mathrm{M}$ of dNTPs in a $12-\mu l$ reaction (26). The reaction was immediately placed on ice and cDNA synthesis was carried out using Superscript III reverse transcriptase (Invitrogen, Carlsberg, CA) using the manufacturer's protocols. Control reactions that lacked reverse transcriptase were also done. PCR was performed under the following conditions: $1 \times$ PCR buffer (New England BioLabs [NEB], Beverly, MA), $0.1 \mathrm{mM}$ dNTP (Promega, Madison, WI), $0.5 \mathrm{mM}$ of forward and reverse primer, $2 \mu \mathrm{l}$ of cDNA, and $1 \mathrm{U}$ of Taq polymerase (NEB) in a final volume of $20 \mu \mathrm{l}$ using cycling parameters: $94^{\circ} \mathrm{C}$ for $3 \mathrm{~min}, 35$ cycles at $94^{\circ} \mathrm{C}$ for $30 \mathrm{~s}, 55^{\circ} \mathrm{C}$ for $30 \mathrm{~s}$ ramping $\left(0.5^{\circ} \mathrm{C} / \mathrm{s}\right)$ to $72^{\circ} \mathrm{C}$ for $1 \mathrm{~min}$, then a final incubation of $72^{\circ} \mathrm{C}$ for $10 \mathrm{~min}$. To validate negative FDV RT-PCR results, a control RT-PCR amplifying a segment of the planthopper or sugarcane actin gene was done from the same RNA extraction. Primers used for RT-PCR are shown in Table 1.

FDV quantitative RT-PCR assay. Quantitative RT-PCR (qRTPCR) was performed on both leaf sections and planthoppers to determine FDV RNA concentrations. Relative quantification of virus RNA was normalized using a planthopper actin gene or a sugarcane $18 \mathrm{~S}$ ribosomal gene for planthopper and sugarcane

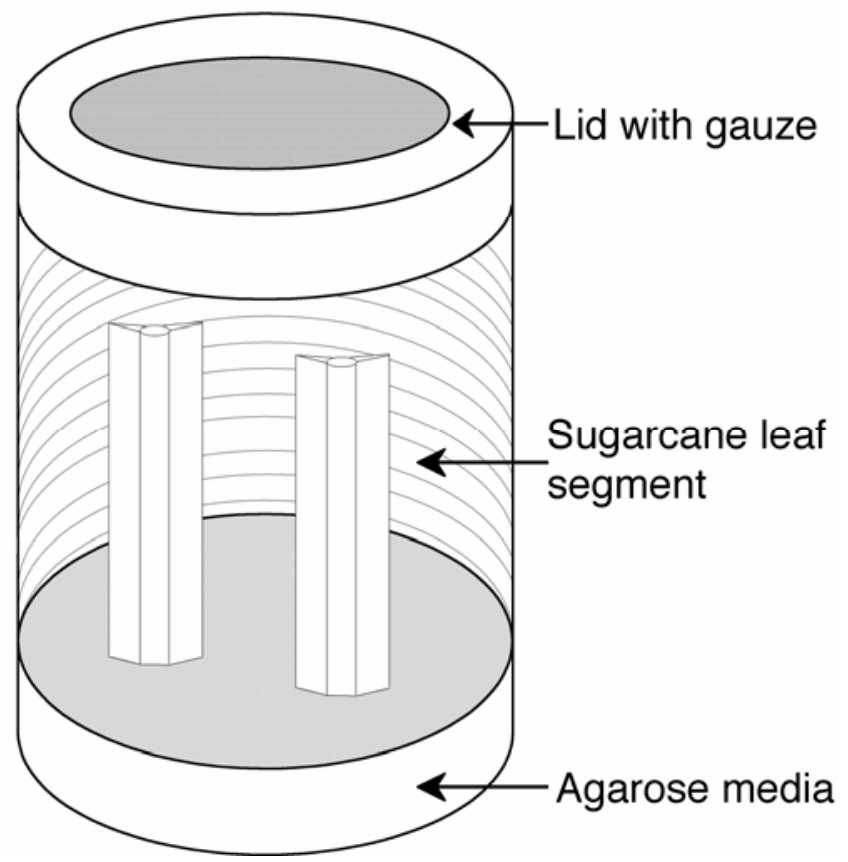

Fig. 1. Leaf segment system for planthopper rearing and virus inoculation assay. Healthy sugarcane leaf segments are embedded in $1 \%$ agarose. Planthoppers feed on and lay eggs into sugarcane segments. Virus inoculation assays are completed with individual planthoppers feeding on smaller virusfree leaf segments. samples, respectively. The RNA extraction and cDNA synthesis was completed as described previously using FDV forward primer (FDVmbgs9F) and either the planthopper actin (PH-Actin-F) or sugarcane $18 \mathrm{~S}$ ribosomal gene (So18F) forward primers (Table 1).

The qRT-PCR was performed in triplicate in a Rotor-Gene 6000 (Corbett, Sydney, Australia) using Platinum SYBR Green I Supermix (Invitrogen) according to the manufacturer's protocol. FDV and 18S ribosomal qRT-PCR was done using a 1-in-10 dilution of cDNA as template, while the planthopper actin qRTPCR used a one-in-five dilution. Primers for the FDV amplification (FDVmgbs9F/FDVmgbs9R) and reference genes (sugarcane: So18F/So18R, planthopper: $\mathrm{PH}-$ Actin-F/PH-Actin-R) are listed in Table 1 . The PCR cycling conditions were $50^{\circ} \mathrm{C}$ for $2 \mathrm{~min}, 95^{\circ} \mathrm{C}$ for $2 \mathrm{~min}, 40$ cycles of $95^{\circ} \mathrm{C}$ for $10^{\circ} \mathrm{C} \mathrm{s}, 60^{\circ} \mathrm{C}$ for $15 \mathrm{~s}\left(62^{\circ} \mathrm{C}\right.$ for $15 \mathrm{~s}$ for planthopper qRT-PCR), and $72^{\circ} \mathrm{C}$ for $20 \mathrm{~s}$ followed by melt curve analysis from 69 to $95^{\circ} \mathrm{C}$. Pooled cDNA from separate samples was used as a calibrator to normalize between qRT-PCR runs and PCR product specificity was determined by melt curve analysis. Crossing threshold values were calculated using comparative quantification analysis using Corbett software. Relative abundance of virus concentration was determined using the method developed by Pfaffl (20).

Experiments using in vitro growth system. qRT-PCR was performed on leaf sections inoculated with FDV from planthoppers that were reared on FDV-infected plant material. Ten planthoppers, reared on FDV-infected sugarcane, were placed on a single sugarcane leaf segment (approximately $2 \times 4 \mathrm{~cm}$ ) embedded in agarose in a glass vial for 1 day. Insects were removed and the leaf sections were frozen at $-80^{\circ} \mathrm{C}$ immediately or 4 days after the removal of insects, and kept frozen until processing for FDV concentration.

We conducted a second experiment to determine the relationship between FDV inoculation of the leaf section and development of FLG in whole plants. Planthoppers were reared on FDVinfected sugarcane (cv. NCo310) at BSES Pathology farm, Woodford in a glasshouse. Single nymphal planthoppers (fourth or fifth instars) were placed on young (3- to 4-week-old) caged healthy sugarcane plants (cv. Q102 - a highly susceptible cultivar) and left for 4 days in glasshouse conditions. Each individual planthopper was then transferred to a glass tube containing a sugarcane leaf segment (cv. Q102) embedded in 1\% agarose. Planthoppers were held on leaf segments for 4 days in insect growth cabinets under the conditions described previously for the rearing of planthoppers. Planthoppers and sugarcane leaf segments were then stored at $-80^{\circ} \mathrm{C}$ until analyzed for FDV infection by RT-PCR.

After the planthoppers were removed and placed onto leaf segments, uncaged sugarcane plants were grown under glasshouse conditions for 4 months and screened for FLG symptoms. The plants were ratooned (pruned to ground level) and grown for another 4 months, after which a second screening for FDV symptoms was completed. Five control plants were grown without FDV-infected insects. Figure 2 depicts the time course of the

TABLE 1. Primers used for reverse transcription-polymerase chain reaction (RT-PCR) and quantitative RT-PCR

\begin{tabular}{llc}
\hline Primer & \multicolumn{1}{c}{ Sequence 5'-3' } & Reference \\
\hline FDV-1 & TCTAAAGTGATTGGACCA & This study \\
FDV-2 & GTTGCTAGGTCGTGAGTTTCGAT & This study \\
PH-F & GCCCATCTACGAAGGTTAC & $(15)$ \\
PH-R & CCATTTCCTGTTCGAAGCCCAG & $(15)$ \\
SC-Actin-F & GAAAGGCCAACAGGGAGAAGA & This study \\
SC-Actin-R & CGTACATGGCAGGAACATTG & This study \\
FDVmgbs9F & CGGAGGTATAACACGCAAACC & $(23)$ \\
FDVmgbs9R & TGTTACTCCTTTTAGAAGTTGGTCGAA & $(23)$ \\
So18SF & GGTGCATGGCCGTTCTTAGTT & $(21)$ \\
So18SR & AGCTAGCTGCGGAGGGAT & $(21)$ \\
PH-Actin-F & TCCCCACGCCATTCTGAGAT & This study \\
PH-Actin-R & GCTTCTCCTTGATGTCGCGC & This study \\
\hline
\end{tabular}


experiment. qRT-PCR analysis was performed on FDV-infected planthoppers to determine the relationship between FDV concentration in the planthopper, inoculation of virus to leaf segment, and development of disease in whole plants. Data were $\log 10$ transformed and analyzed using the generalized least squares function in the nonlinear mixed effects package using the $\mathrm{R}$ computer program (22).

\section{RESULTS}

Growth of planthoppers in vitro. A colony of $P$. saccharicida was reared successfully and maintained on sugarcane leaf segments embedded in agarose in containers incubated in insect growth cabinets. Insects mated and laid eggs into the midrib of the sugarcane leaf segments and emerging nymphs were collected and transferred to new leaf segments. The colony was maintained continuously for approximately 2 years (40 generations) using this in vitro system.

Detection of FDV within sugarcane leaves. To determine if insects could inoculate FDV into leaves, planthoppers reared on FDV infected sugarcane were exposed to healthy leaf segments. FDV was detected by RT-PCR of total RNA in sugarcane leaf segments inoculated by pools of 10 planthoppers. Additionally, the virus could also be detected in leaf segments inoculated by single planthoppers. This technique provides a nondestructive assay to assess the vector competence of planthoppers. We observed no statistically significant difference in FDV RNA concentration in leaf segments incubated for 0 days and 4 days postinoculation with mean relative abundance of 0.02 (SEM $=0.008$, $n=10)$ and $0.07(\mathrm{SEM}=0.02, n=9)$ for day 0 and day 4 samples, respectively.

FDV inoculation and transmission assay. To determine the biological relevance of the inoculation assay, detection of the virus in the leaf segment was compared with transmission of virus to the plant and subsequent development of disease. Single planthoppers reared on FDV-infected cane were allowed to feed on whole, healthy sugarcane plants, and then transferred to sugarcane leaf segments and symptoms were assessed in the plant. Virus was assayed in the leaf segment and planthoppers using RTPCR. Of the 176 planthoppers tested, in 96 cases no virus was detected in the planthopper and as expected, in each of these cases no symptoms were observed on the plants (Fig. 3). Of the 80 planthoppers that contained virus, 27 generated leaf segments with detectable virus and 9 of the planthoppers transmitted virus to plants that resulted in development of disease symptoms. No cases were recorded where symptoms developed in plants but the leaf segment was negative for FDV. No control plants or leaf segments were positive for FDV or disease symptoms.

The relative concentration of virus in planthoppers with different transmission competence was compared by qRT-PCR. Analysis of variance (ANOVA) revealed the FDV RNA levels within planthoppers were significantly different for planthoppers that did not inoculate or transmit, planthoppers that inoculated the leaf segment only, and planthoppers that inoculated the leaf segment and transmitted FDV to plants, which subsequently led to development of FLG symptoms (Table 2).

\section{DISCUSSION}

The FDV-Perkinsiella-sugarcane system is not ideal for investigating transmission dynamics because of the low competence of the vector to transmit FDV and the length of time associated with plants to develop FLG symptoms. Understanding virusvector interactions is crucial for implementation of control strategies for the disease. A simple assay for vector competence for individual insects will facilitate research within the FDV-Perkinsiella-sugarcane system. We devised a technique that facilitates laboratory-based rearing of $P$. saccharicida and enables rapid

\section{Plant inoculation}

\section{Symptom development in plant}

\section{Aquisition period}

Leaf segment inoculation

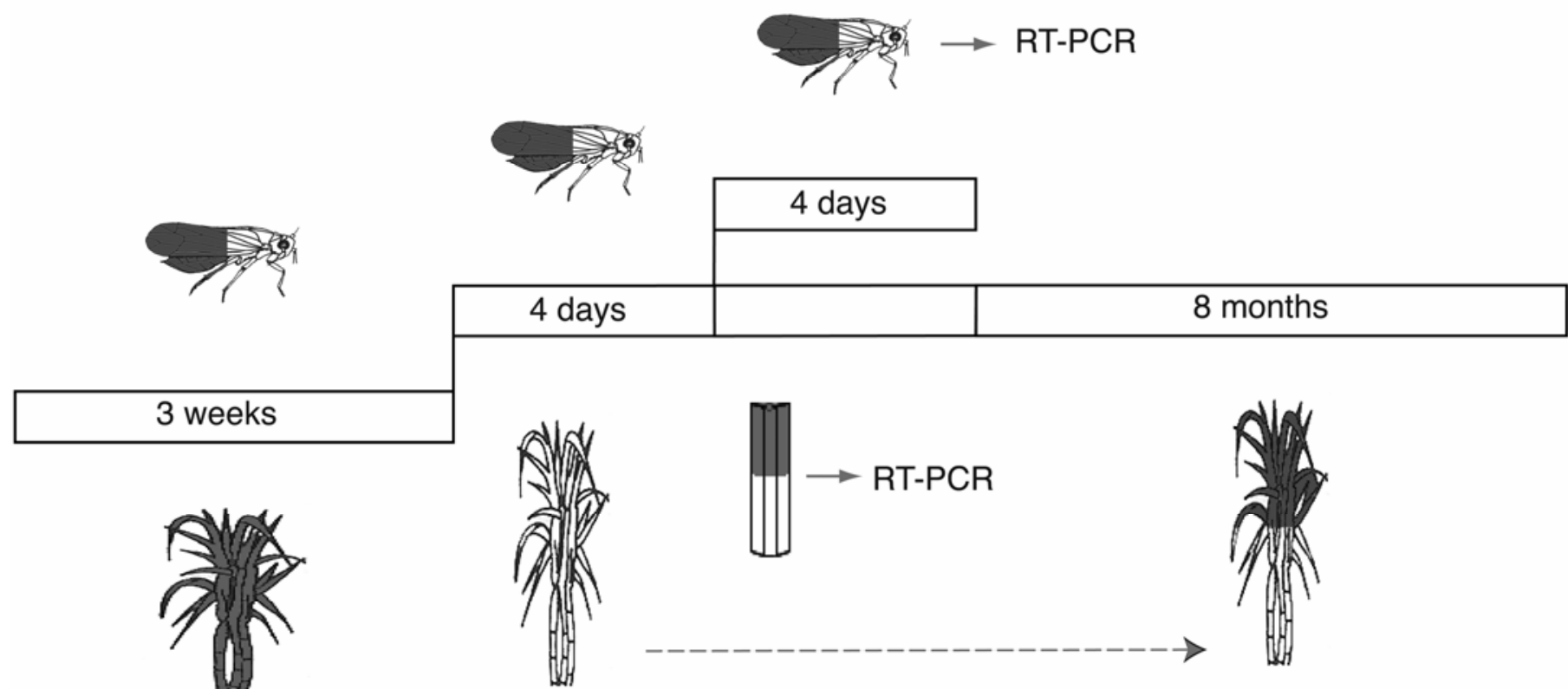

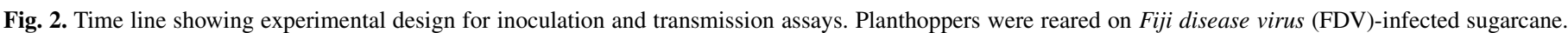

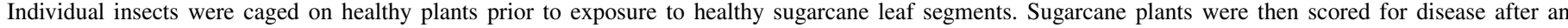

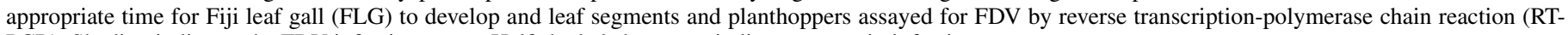
PCR). Shading indicates the FDV infection status. Half shaded characters indicate uncertain infection status. 
nondestructive determination of the vector competence of planthoppers. A relationship was observed between inoculated leaf segments in vitro and development of FLG symptoms within sugarcane plants. Additionally, a significant difference in virus titer was observed between inoculating and transmitting planthoppers suggesting that a threshold concentration of FDV RNA within the planthopper may be required for the insect to act as a successful vector under the experimental conditions of the assay.

Laboratory-based rearing of planthoppers provides a technique amenable to experimental manipulation and replication. It also removes fluctuating environmental conditions that can be associated with glasshouses and mass rearing. The use of sugarcane leaf segments as a substrate mimics the natural environment and provides a simple and inexpensive method to culture insects. In addition to rearing, the chambers can be used for single planthopper pairs for specific matings, and establishment of isofemale lines. Virus detection by RT-PCR in leaf segments allows determination of a measure of vector competence of individual planthoppers.

The ability of an individual planthopper to inoculate a leaf segment was compared to the development of disease symptoms in whole plants fed upon by the same planthopper. Of the 80 cases where planthoppers contained detectable virus, 9 were associated with disease development in plants. Each of these nine planthoppers also inoculated the leaf segment on which they were reared. No cases were recorded where plants displayed symptoms but planthoppers did not inoculate leaf samples. An additional 18 cases were observed where planthoppers inoculated leaf segments but symptoms were not observed in plants. These data indicate that the leaf inoculation assay is robust, but overestimates the development of FLG disease in sugarcane plants fed upon by single planthoppers. This overestimation is likely to reflect the dynamic interplay between whole plant and virus that will not always lead to the development of disease from a given inoculation. Inoculation of the virus into the plant is most probably one of several steps required for plants to display disease symptoms.
Alternatively, feeding preferences, the number of probing events, and egestion-ingestion may differ between whole plants and leaf segments.

The occurrence of high virus RNA levels within insects associated with both successful inoculation of leaf segments and disease symptom development in whole plants suggests that a threshold virus concentration within the planthopper may be required to successfully transmit FDV. Quantification of FDV RNA may be an alternative indirect measure of vector competence for individual planthoppers (Table 2), but requires the destruction of the insect. Again this approach may overestimate transmission since a small minority noninoculating planthoppers had virus RNA concentrations that were similar to those that fed on plants that subsequently developed disease symptoms. Salivary-gland virus levels may be an even more appropriate measure of an insect's vector competence, however the accurate dissection of glands, especially from immature planthoppers is technically challenging and quite laborious.

Development of future paratransgenic $(3,4,7)$, or transgenic $(14,16)$ control strategies that target FDV transmission will require the identification of antagonist molecules that reduce or inhibit FDV transmission from the planthopper to sugarcane (e.g., single chain antibodies targeting key viral proteins). Utilization of this technique, by either assaying FDV inoculation to leaf seg-

TABLE 2. Relative abundance of Fiji disease virus (FDV) RNA within FDVinfected planthoppers

\begin{tabular}{lccc}
\hline $\begin{array}{l}\text { Transmission potential } \\
\text { of planthopper }\end{array}$ & $\begin{array}{c}\text { Mean relative } \\
\text { abundance of } \\
\text { FDV (SEM) }\end{array}$ & $\begin{array}{c}P \text { value for } \\
\text { interaction between } \\
\text { groups (ANOVA) }\end{array}$ \\
\hline $\begin{array}{lccc}\text { (a) No inoculation or transmission } \\
\text { (b) Inoculation of leaf segment only }\end{array}$ & $\begin{array}{c}15.9(3.1) \\
\text { (c) Inoculation of leaf segment and } \\
\text { development of disease symptoms }\end{array}$ & $\begin{array}{l}\mathrm{a} \times \mathrm{b} \\
\mathrm{b} \times \mathrm{c}\end{array}$ & 0.0024 \\
\hline
\end{tabular}

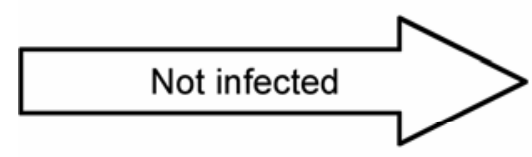

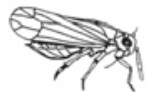

96
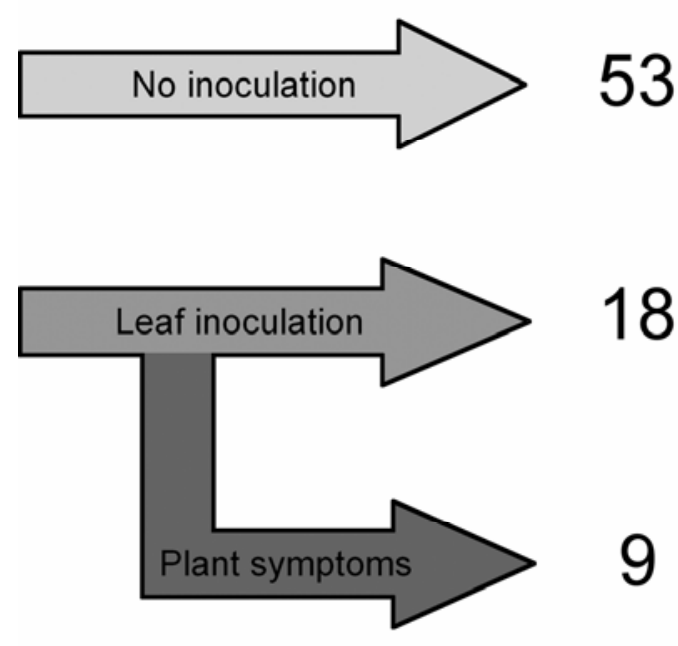

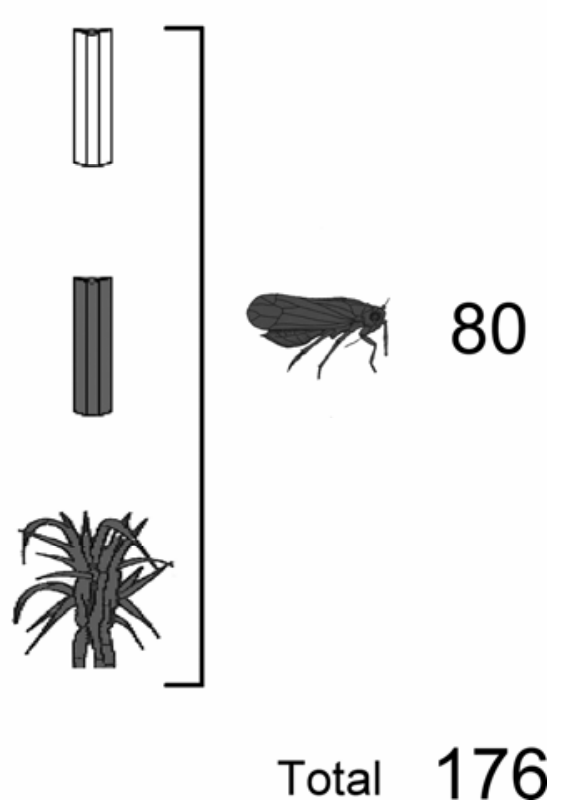

Total 176

Fig. 3. Schematic showing the infection status of planthoppers and sugarcane plants and leaf segments used in the inoculation and transmission experiment. Shaded characters are Fiji disease virus (FDV)-infected, while clear are virus-free. Of the 80 virus positive planthoppers, 27 either inoculated the leaf segment or transferred symptoms to the plant. Nine planthoppers transmitted virus to sugarcane that subsequently caused disease in plants. 
ments or by quantification of FDV RNA within the planthopper, or both simultaneously, provides a potential strategy to evaluate the efficacy of such molecules after introduction into the planthopper.

\section{ACKNOWLEDGMENTS}

We thank B. Croft for comments on experimental design, A. Anderson and A. Ridley for assistance with transmission assays, S. Blomberg for statistical advice, P. Cook and B. Simpson for qRT-PCR advice, and members of the O'Neill laboratory for technical assistance. This research was supported by an Australian Research Council Linkage grant in association with BSES Limited.

\section{LITERATURE CITED}

1. Anonymous. 1979. Bureau of Sugar Experiment Stations, 79th Annual Report, Brisbane.

2. Baber, E. G., and Robinson, P. E. 1950. Feeding habits of Perkinsiella saccharicida. Proc. Int. Soc. Sugar Cane Technol. 7:155-167.

3. Beard, C. B., Durvasula, R. V., and Richards, F. F. 1998. Bacterial symbiosis in arthropods and the control of disease transmission. Emerg. Infect. Dis. 4:581-591.

4. Beard, C. B., Mason, P. W., Aksoy, S., Tesh, R. B., and Richards, F. F. 1992. Transformation of an insect symbiont and expression of a foreign gene in the Chagas' disease vector Rhodnius prolixus. Am. J. Trop. Med. Hyg. 46:195-200.

5. Croft, B. J., James, P. J., Ridley, A. W., and Smith, G. R. 2004. Developing methods to screen sugarcane varieties for resistance to Fiji Leaf Gall. Proc. Aust. Soc. Sugar Cane Technol. 26:1-11.

6. Croft, B. J., Margarey, R., and Whittle, P. 2000. Disease management. Pages 263-289 in: Manual of Canegrowing. D. M. Hogarth and P. G. Allsopp, ed. Bureau of Sugar Experiment Stations, Brisbane.

7. Durvasula, R. V., Gumbs, A., Panackal, A., Kruglov, O., Aksoy, S., Merrifield, R. B., Richards, F. F., and Beard, C. B. 1997. Prevention of insect-borne disease: An approach using transgenic symbiotic bacteria. Proc. Natl. Acad. Sci. 94:3274-3278.

8. Egan, B. T., and Ryan, C. C. 1986. Predicting disease incidence and yield losses in sugarcane in a Fiji disease epidemic. Pages 443-457 in: Plant Virus Epidemics: Monitoring, Modelling and Predicting Outbreaks. G. D. McLean, R. G. Garrett, and W. G. Ruesink, eds. Academic Press, Sydney.

9. Egan, B. T., Ryan, C. C., and Francki, R. I. B. 1989. Fiji disease. Pages 263-288 in: Diseases of Sugarcane-Major Diseases. C. Ricaud, B. T. Egan, A. G. J. Gillaspie, and C. G. Hughes, eds. Elsevier, Amsterdam.

10. Francki, R. I., and Grivell, C. J. 1972. Occurrence of similar particles in Fiji disease virus-infected sugar cane and insect vector cells. Virology 48:305-307.
11. Francki, R. I. B., Ryan, C. C., Hatta, T., Rohozinski, J., and Grivell, C. J. 1986. Serological detection of Fiji disease virus antigens in the planthopper Perkinsiella saccharicida and its inefficient ability to transmit the virus. Plant Pathol. 35:324-328.

12. Fu, Q., Zhang, Z., Hu, C., Lai, F., and Sun, Z. 2001. A chemically defined diet enables continuous rearing of the brown planthopper, Nilaparvata lugens (Stål) (Homoptera:Delphacidae). Appl. Entomol. Zool. 36:111116.

13. Hughes, C. G., and Robinson, P. E. 1961. Fiji Disease. Pages 389-405 in: Sugarcane Diseases of the World, Vol. 1. J. P. Martin, E. V. Abbott, and C. G. Hughes, eds. Elsevier, Amsterdam.

14. Ito, J., Ghosh, A., Moreira, L. A., Wimmer, E. A., and Jacobs-Lorena, M. 2002. Transgenic anopheline mosquitoes impaired in transmission of a malaria parasite. Nature 417:452-455.

15. Lijun, C., Xizhi, M., Lin, K., Kejing, D., Shouyuan, Z., and Changben, L. 2003. Detecting Rice stripe virus (RSV) in the small brown planthopper (Laodelphax striatellus) with high specificity by RT-PCR. J. Virol. Methods 112:115-120.

16. Marrelli, M. T., Li, C., Rasgon, J. L., and Jacobs-Lorena, M. 2007. Transgenic malaria-resistant mosquitoes have a fitness advantage when feeding on Plasmodium-infected blood. Proc. Natl. Acad. Sci. 104:55805583.

17. Mitsuhashi, J. 1974. Methods for rearing leafhoppers and planthoppers on artificial diets. Rev. Plant Prot. Res. 7:57-67.

18. Mitsuhashi, J., and Koyama, K. 1971. Rearing of planthoppers on a holidic diet. Entomol. Exp. Appl. 14:93-98.

19. Mungomery, R. W., and Bell, A. F. 1933. Fiji disease of sugar-cane and its transmission. Division of Pathology Bureau of Sugar Experiment Stations Bulletin 4.

20. Pfaffl, M. W. 2001. A new mathematical model for relative quantification in real-time RT-PCR. Nucleic Acids Res. 29:e45.

21. Purnell, M. P., Petrasovits, L. A., Nielsen, L. K., and Brumbley, S. M. 2007. Spatio-temporal characterization of polyhydroxybutyrate accumulation in sugarcane. Plant Biotechnol. J. 5:173-184.

22. R Development Core Team. 2007. R: A language and environment for statistical computing. R Foundation for Statistical Computing, Vienna, Austria.

23. Ridley, A. 2005. A study of planthoppers as vectors of Fiji disease virus of sugarcane. Ph.D. thesis. The University of Queensland, Brisbane.

24. Smith, G. R. 2000. Fiji disease. Pages 239-244 in: A Guide to Sugarcane Diseases. P. Rott, R. A. Bailey, J. C. Comstock, B. J. Croft, and S. A. Saumtally, eds. Cirad, Montpellier, France.

25. Smith, G. R., and Candy, J. M. 2004. Improving Fiji disease resistance screening trails in sugarcane by considering virus transmission class and possible origin of Fiji disease virus. Aust. J. Agric. Res. 55:665672.

26. Smith, G. R., Van de Velde, R., and Dale, J. L. 1992. PCR amplification of a specific double-stranded RNA region of Fiji disease virus from diseased sugarcane. J. Virol. Methods 39:237-246. 